\title{
Peptide Nanofibers with Dynamic Instability through Non- Equilibrium Biocatalytic Assembly
}

\author{
Sisir Debnath, Sangita Roy, Rein V. Ulijn* \\ WestCHEM, Department of Pure and Applied Chemistry, University of Strathclyde, 295 \\ Cathedral Street, Glasgow, G1 1XL, UK.
}

\begin{abstract}
We demonstrate supramolecular peptide nanofibers that display dynamic instability, i.e. they are formed by competing assembly and dis-assembly reactions, where assembly is favoured away from equilibrium. The systems are based on competitive catalytic transacylation and hydrolysis, producing a self-assembling aromatic peptide derivative from amino acid precursors, that temporarily exceeds the critical gelation concentration, until the competing hydrolytic reaction takes over. Analysis by atomic force microscopy shows consecutive nanofiber formation and shortening. The process results in macroscopically observable temporary hydrogelation, which may be repeated upon refuelling the system with further addition of the chemically activated amino acid pre-cursor. Non-equilibrium nanostructures open up opportunities for mimicry of the behaviour dynamic gels found in natural systems and provide components for future adaptive nanotechnologies.
\end{abstract}

Results and Discussion: The combination molecular self-assembly ${ }^{1}$ and (bio-)catalysis underlies dynamic processes in biology and also provides a useful paradigm for fabrication of adaptive nanostructures. ${ }^{2}$ A key feature of naturally occurring catalytic self-assembling systems is that they are dynamic in nature, with lengthening and breakdown tightly regulated. For example, catalytic formation and degradation of actin filaments ${ }^{3}$ and microtubules ${ }^{4}$ underlie vital cellular functions such as motility, differentiation, division. Synthetic mimics of these systems have been the focus of considerable research efforts in recent years. ${ }^{1,2}$ One feature where most man-made systems differ from their natural counterparts, is that the latter (e.g. microtubules) display dynamic instability, in that they are assembled and lengthened in a process that relies on energy input (away from equilibrium) and shortened when equilibrium is approached. Significant effort is currently invested in developing non-equilibrium molecular systems ${ }^{5}$ and materials which may give rise to new features that are normally not associated with synthetic systems, in that they may be reconfigurable, externally fuelled, self-healing, or even self-replicating. ${ }^{6}$

Boekhoven et al., recently published a first example of a non-equilibrium catalytic self-assembly system demonstrating temporary hydrogelation based on catalytic esterification of a di-acid. ${ }^{7}$ Von Maltzahn et al. demonstrated a non-equilibrium biocatalytic nanoparticle assembly system which could assemble upon kinase/ adenosine triphosphate (ATP) driven phosphorylation and subsequently dis-assemble in response to a phosphatase enzyme. ${ }^{8}$ ATP driven biocatalytic assembly /disassembly of supramolecular fibers has also been demonstrated using phosphatase/kinase systems. ${ }^{9}$ However, for these systems the ATP driven reaction results in formation of the phosphorylated, non-assembling species and these are therefore not examples of dynamic instability or non-equilibrium self-assembly. 
Thus, we set out to produce non-equilibrium biocatalytic self-assembled systems displaying dynamic instability. The requirements for such a system are the following: (i) the product of the forward reaction should have a tendency for unidirectional self-assembly; (ii) forward and backward reactions to produce/degrade gelator molecules should follow distinct routes; (iii) conditions must be chosen where the critical assembly concentration to form nanofibers is higher than the equilibrium yield of the enzymatic peptide synthesis reaction.

In order to satisfy criterion 1, our system is based on naphthalene-dipeptide gelators where the $\mathrm{N}$-terminus is functionalized with an aromatic group, napthoxyacetyl (Nap). ${ }^{10} \mathrm{We}$ used Nap-dipeptide molecules which spontaneously assemble into unidirectional nanofibers through a combination of $\pi$-stacking interactions between the aromatic groups and hydrogen bonding interactions between the peptide backbones, ultimately forming a selfsupporting hydrogel. ${ }^{10}$ We recently demonstrated that enzymatic condensation of suitable pairs of naphthalene-amino acid with hydrophobic amino acid amides gives Nap-peptide$\mathrm{NH}_{2}$ which are highly efficient in hydrogelation. ${ }^{10 \mathrm{c}}$

Proteases are known to catalyzed the synthesis (rather than hydrolysis) of peptides under appropriate conditions. ${ }^{11}$ This has been demonstrated e.g., in organic media, at solid/liquid interfaces or in highly concentrated heterogeneous systems. We previously demonstrated that molecular self-assembly may also provide a suitable thermodynamic driving force, where the relative stabilization of the peptide product through self-assembly provides a driving force to favour peptide synthesis. ${ }^{12}$

$\alpha$-Chymotrypsin is well known for its ability to catalyze peptide synthesis starting from a suitable ester precursor to kinetically overcome the bias for hydrolysis in aqueous systems $^{11}$. Qin et al. recently used this enzyme for biocatalytic self-assembly by using dipeptide esters instead of free acids to form polypeptides that resulted in stable selfassembling structures, produced via transacylation using $\alpha$-chymotrypsin and papain. ${ }^{13}$ Based on this work and in order to meet criterion ii, we used $\alpha$-chymotrypsin catalyzed transacylation for the forward reaction (under kinetic control), with the competing, disassembly reaction based on amide hydrolysis (under thermodynamic control).

Specifically, we used as the acyl donor tyrosine methyl ester, (1, Figure 1A) with a series of hydrophobic amino acids, functionalized as amides at $\mathrm{C}$-terminus: L-tyrosine amide $\left(\mathrm{Y}-\mathrm{NH}_{2}\right)$, L-phenylalanine amide $\left(\mathrm{F}-\mathrm{NH}_{2}\right)$, L-leucine amide $\left(\mathrm{L}-\mathrm{NH}_{2}\right)$, to yield the dipeptide amides (2, Figure $1 \mathrm{~A}$, Table 1$)$ and reactions were followed using high performance liquid chromatography (HPLC). Effective transacylation reactions were observed in presence of $\alpha-$ chymotrypsin. The starting material, Nap-Y-OMe (1) disappeared within $1 \mathrm{~min}$ and the conversion to the dipeptide product, Nap- $\mathrm{YX}-\mathrm{NH}_{2}$, (2) reached a maximum within 2-3 min. The product eventually broke down to the corresponding acid, Nap-Y-OH, (3) with time. 1 was completely converted through hydrolysis to $\mathbf{3}$ and acylation to $\mathbf{2}$. Over time, amide hydrolysis of $\mathbf{2}$ to form $\mathbf{3}$ and $\mathbf{4}$ starts to compete and the system eventually reached an equilibrium situation. As is shown in Figure $1 \mathrm{~B}$ and $1 \mathrm{C}$, there are now two different possible scenarios, resulting in equilibrium or non-equilibrium hydrogelation. Depending on the critical gelation concentration (CGC) of the system, it either reverts back to a solution (equilibrium conversion of $\mathbf{2}<\mathrm{CGC}$, as observed for Nap-YY-NH , and Nap-YL-NH $\mathrm{NH}_{2}$ with negligible peptide present at equilibrium) (criterion iii is met, non-equilibrium hydrogelation), or it remains as a gel (equilibrium conversion of $\mathbf{2}>$ CGC as observed for Nap- 
YF- $-\mathrm{NH}_{2}$, giving rise to $30 \%$ final conversion). ${ }^{14}$ In either scenario, the final state of the system (hydrogel or solution) is dictated by the self-assembly propensity of the Nappeptide- $\mathrm{NH}_{2}$.
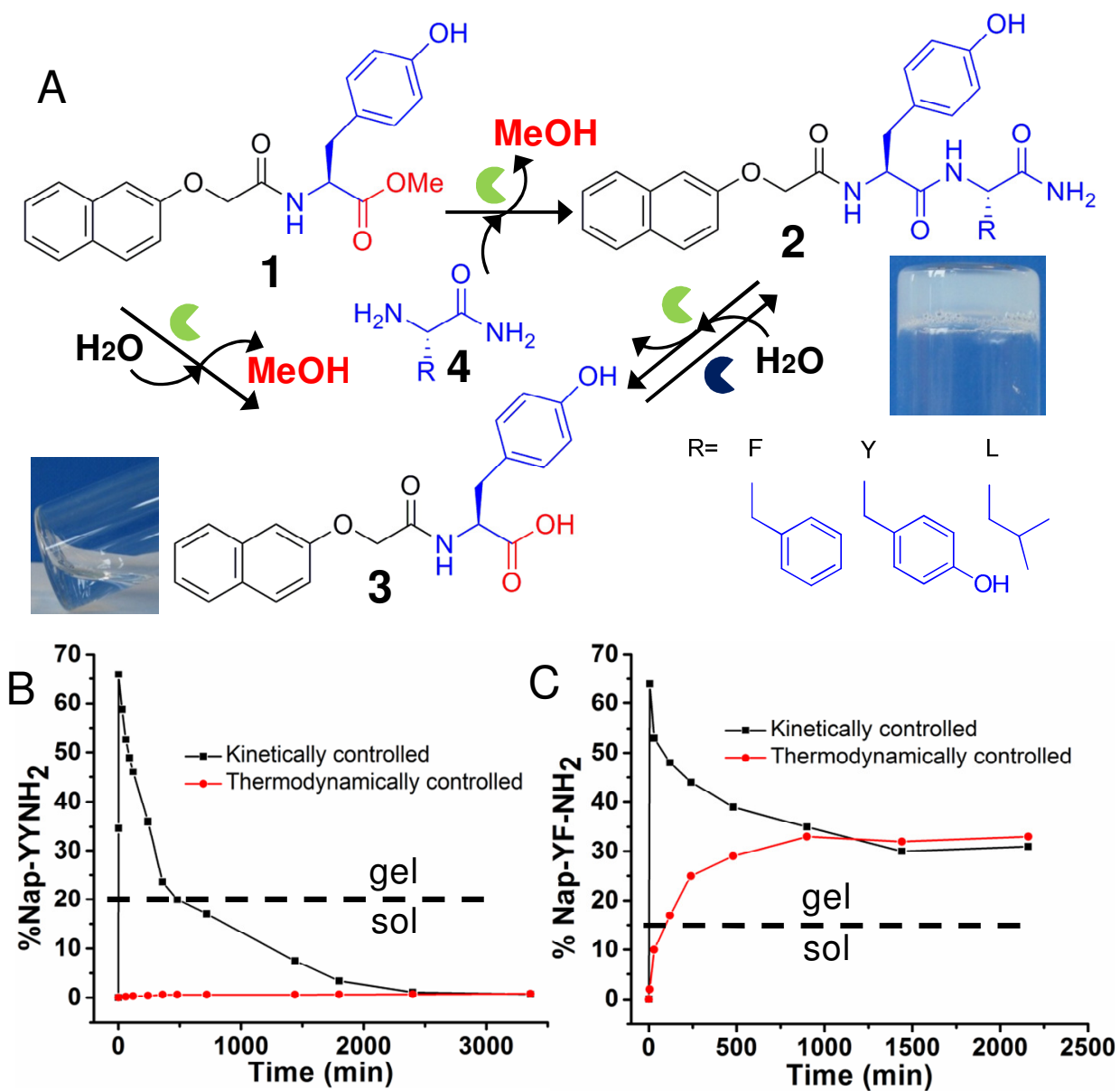

Figure 1. Non-equilibrium biocatalytic self-assembly (A) Nap-Y-OMe (1) and different amino acid amides $\left(\mathrm{X}-\mathrm{NH}_{2}\right)(\mathbf{4})$ in presence of chymotrypsin (green) form the (temporary) hydrogelator (2) which may also be hydrolysed by the same enzyme to Nap-Y-OH (3) and 4. Thermolysin (blue) catalyzes the reversible hydrolysis/condensation of 2. (B) Nonequilibrium assembly and hydrogelation. Time course of the kinetically controlled reaction (chymotrypsin catalyzed) of $\mathrm{Nap}-\mathrm{Y}$-OMe (black line) and thermodynamically controlled reaction (thermolysin catalyzed) of $\mathrm{Nap}-\mathrm{Y}-\mathrm{OH}$ (red line) with $\mathrm{Y}$ $\mathrm{NH}_{2}$ at $\mathrm{pH}$ 8. (C) Reactions of Nap-Y-OMe (black line) and $\mathrm{Nap}-\mathrm{Y}-\mathrm{OH}$ (red line) with $\mathrm{F}-\mathrm{NH}_{2}$ by chymotrypsin and thermolysin respectively at $\mathrm{pH} 8$.

To demonstrate that the final conversions indeed represent equilibrium, we used $\mathrm{Nap}-\mathrm{Y}-\mathrm{OH}$ (3), the free carboxylic acid as the acyl donor to couple with $\mathrm{F}-\mathrm{NH}_{2}$ (4). The process was found to be slow and took $>96$ hours to reach to equilibrium (Figure S1). To study the equilibrium position of this reaction, we therefore used thermolysin, an enzyme that was previously shown to be highly efficient in catalyzing direct condensation of free acids and amies, ${ }^{10 c, 12}$ to directly couple free acid $\mathbf{3}$ and nucleophile $\mathbf{4}$ to form peptide derivative 2 (Figure $1 \mathrm{~A}$ ). $\mathrm{Nap}-\mathrm{Y}-\mathrm{OH}$ reacts with the $\mathrm{Y}-\mathrm{NH}_{2}$ or $\mathrm{F}-\mathrm{NH}_{2}$, giving rise to an identical final yield (Figures $1 \mathrm{~B}-\mathrm{C}$ and Figure $\mathrm{S} 2, \mathrm{~S} 3$ ) remaining a solution with negligible conversion to Nap-YY-NH ${ }_{2}$, and Nap-YF- $\mathrm{NH}_{2}$ forming a gel. Table 1 (see also Figures S2, S3, S4, S5 and S6) shows the corresponding conversion to the naphthalene dipeptide products and their subsequent hydrolysis. 
Table 1. Chymotrypsin triggered self-assembly and dis-assembly of Nap-Y-OMe and different amino acid amides

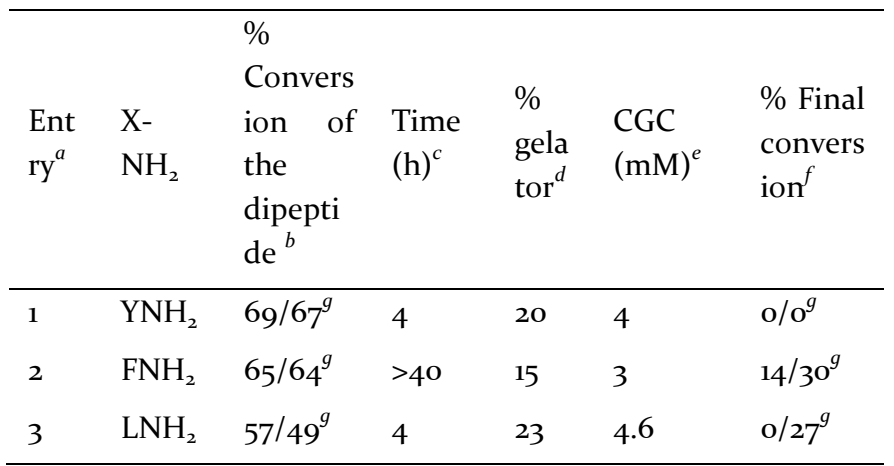

${ }^{a}$ All reactions performed at $20 \mathrm{mM}$ concentration of both $\mathrm{Nap}-\mathrm{Y}$-OMe and $\mathrm{X}-\mathrm{NH}_{2}$ with $1 \mathrm{mg}$ of $\alpha$-chymotrypsin (lyophilized powder) at $\mathrm{pH} 10 .{ }^{b}$ Conversion reached within 5 minutes. ${ }^{c}$ Life time of macroscopically observed gel phase. ${ }^{d} \%$ of the corresponding gelator during macroscopic transition from gel to sol phase. ${ }^{e} \mathrm{CGC}$ were estimated by $\%$ gelator present during observed gel-sol transition. ${ }^{f}$ Final conversions were taken after $40 \mathrm{~h} .{ }^{g}$ These conversions are obtained at $\mathrm{pH} 8$.

The life time of the gel could be tuned by changing the $\mathrm{pH}$ of the solution. Indeed, the dynamic character of the system, i.e. the change in the self-assembly and dis-assembly was found to be enhanced at considerably alkaline $\mathrm{pH}(10)(8 \mathrm{~h})$, compared to $\mathrm{pH} 8$ (36 h) (Table 1 and Figure S7). The Nap-YY- $\mathrm{NH}_{2}$ system at $\mathrm{pH} 10$ was therefore selected for further study.

Figure $2 \mathrm{~A}$ shows the macroscopic appearance of the reaction mixture over time at $\mathrm{pH} 10$ was followed showed that peptide formation reaction is almost instantaneous (Figure S8). To probe the structural changes in the microscopic level, atomic force microscopy (AFM) was carried out at different time points (Figure 2B-E). Early stage AFM showed highly entangled fiber network morphology for the Nap-YY- $\mathrm{NH}_{2}$ hydrogels. These fibers were found to be $>10$ microns in length (Figure 2B). After $3 \mathrm{~h}$ AFM showed substantial shortening of fibers, 5-6 $\mu \mathrm{m}$ long, however, at this stage the gel remained intact owing to the presence of 2 at a concentration of $35-40 \%$, i.e. above the CGC (Figure 2C). At 5 h, we observed even shorter fibers of length 2-3 $\mathrm{m}$ (Figure 2D), corresponding to a viscous phase with a concentration of Nap-YY- $\mathrm{NH}_{2} \sim 15 \%$, as evident from the HPLC (Figure S8). On complete hydrolysis of the dipeptide amide, we observe formation of spherical aggregates, representing $\mathrm{Nap}-\mathrm{Y}-\mathrm{OH}$, resulting in the formation of the free flowing solution (Figure $2 \mathrm{E}$ ). This shortening of fibers provides clear evidence of a dynamically unstable system.

In order to assess the possibility to tune the life time of the gel, we varied the enzyme concentrations from $0.05-3 \mathrm{mg} / \mathrm{mL}$ (Figure $2 \mathrm{~F}$ and $\mathrm{S} 8, \mathrm{~S} 9$ ). The initial coupling step showed limited dependence on enzyme amounts when the concentration of the enzyme is $>0.5 \mathrm{mg} / \mathrm{mL}$ (Figure $2 \mathrm{~F}$ ). The competing reaction, i.e. the hydrolysis of the dipeptide amide was however found to sensitive to the enzyme concentration. At $0.5 \mathrm{mg} / \mathrm{mL}$, complete dissolution occurs after $16 \mathrm{~h}$ while with $3 \mathrm{mg} / \mathrm{mL}$ enzyme, complete dissociation takes place within only $3 \mathrm{~h}$. At lower concentration of enzyme $(0.1$ and $0.05 \mathrm{mg} / \mathrm{mL})$, both the initial coupling step as well as the hydrolysis of the dipeptide depend on the concentration. For 0.1 and $0.05 \mathrm{mg} / \mathrm{mL}$ the maximum conversion was found to be $59 \%$ and $52 \%$ respectively compared to $69 \%$ for $1 \mathrm{mg} / \mathrm{mL}$. The hydrolysis step was also found to be much slower, even 

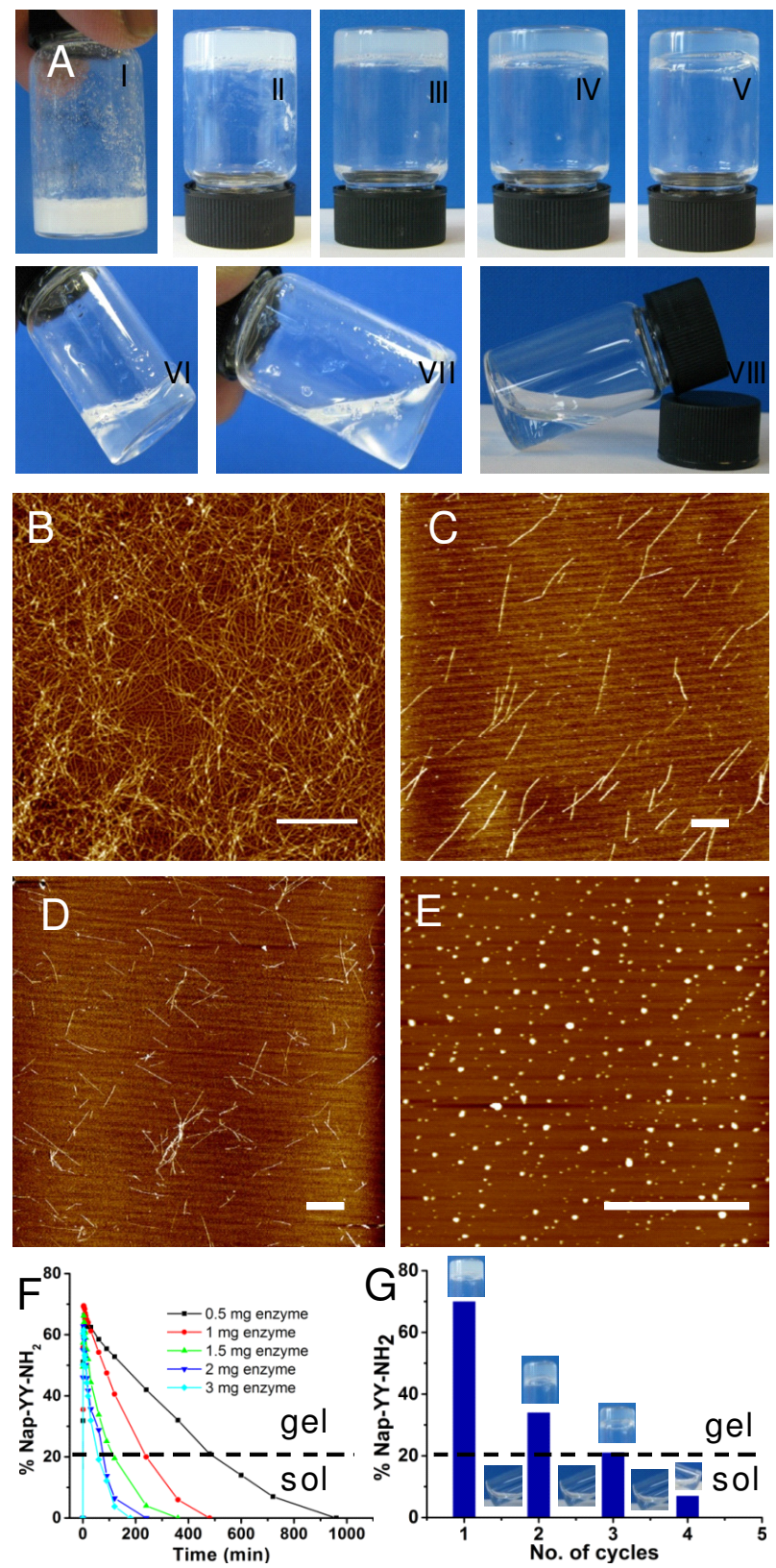

Figure 2. (A) (I-VIII) Photograph of the gel of Nap-YY- $\mathrm{NH}_{2}$ (prepared by $1 \mathrm{mg}$ of chymotrypsin, $\mathrm{pH} 10$ ) at $1 \mathrm{~min}, 5 \mathrm{~min}, 1,2,3$, 4,5 , and 8 hours respectively after the reaction. (B-E) AFM images of the morphology of Nap-YY- $\mathrm{NH}_{2}$ at 30 min, 3,5 and 8 hours respectively (scale bar represent 2 [M). (F) Synthesis and degradation of Nap-YY- $\mathrm{NH}_{2}$ in the course of time in the presence of 0.5-3 mg of chymotrypsin. (G) Refueling the system with Nap-Y-OMe to form the gel repeatedly.

after 7 days $9 \%$ of the product Nap-YY- $\mathrm{NH}_{2}$ has been detected for $0.05 \mathrm{mg} / \mathrm{mL}$ of enzyme concentration (Figure S9). These results showed that gel life time can easily be controlled by changing the concentration of enzyme. The nanofibers did not have significant inhibitory effects on the enzyme since different densities of fibers gave similar degradation rates (Figure S10).

To investigate the possibility of repeated temporary hydrogelation, we added another equivalent of $\mathbf{1}$ (after 24 hours) and found that on refueling, fibers were formed and eventually broken down again. This process could be repeated up to 3 cycles, after which the dipeptide conversion could not reach the CGC, thought to be related to accumulation of $\mathrm{Nap}-\mathrm{Y}-\mathrm{OH}$ in the system, since the presence of $\mathrm{Nap}-\mathrm{Y}-\mathrm{OH}$ reduces final yield (Figure S11). In 
future, in situ reactivation of $\mathrm{Nap}-\mathrm{Y}-\mathrm{OH}$ to $\mathrm{Nap}-\mathrm{Y}-\mathrm{OMe}$ would provide an interesting direction. Attempts to refuel by esterification of $\mathrm{Nap}-\mathrm{Y}-\mathrm{OH}$ to Nap-Y-OMe using methyl iodide, as demonstrated previously by Boekhoven et al. ${ }^{7}$, lacks selectivity required for the peptide based system used here and we are currently seeking biocatalytic routes to achieve in situ reactivation.

Insights into supramolecular interactions underpinning the system were obtained through fluorescence and circular dichroism spectroscopy. $\pi$-Stacking interactions between the aromatic groups are known to be the major driving force in the self-assembly of the aromatic peptide amphiphiles. ${ }^{10}$ These interactions can be monitored using fluorescence spectroscopy, which shows the change in the environment of the naphthalene fluorophore. Fluorescence emission spectra of Nap-YY- $\mathrm{NH}_{2}$ showed a characteristics peak at $355 \mathrm{~nm}$ (Figure S12A). We observed a sharp quenching of the monomeric emission in the initial few minutes owing to the formation of the dipeptide amide and their subsequent self-assembly (Figure S12A inset). Red-shifted excimer peak ${ }^{15}$ at higher wavelength as observed previously with other aromatic groups were not observed.

Chirally organized aromatics in the gel state are known to give rise to intense circular dichroism (CD) signals. ${ }^{16}$ Such $C D$ signals arise from the chiral organization of the selfassembling building blocks in the gel state, rather than from the inherent molecular chirality of the chromophores. During the initial few minutes, we observed an extensive CD signal with two maxima at 290 and $335 \mathrm{~nm}$, corresponding to $\pi-\pi^{*}$ and $n-\pi^{*}$ transition of the naphthalene chromophore (Figure S12B). ${ }^{10 a, c}$ With time the intensity of the CD signal was found to be reduced in intensity (Figure S12B inset), owing to the breakdown of the supramolecular assembly of the dipeptide product to the corresponding acid. After $8 \mathrm{~h}$ the system was $\mathrm{CD}$ silent which was indicative of complete disassembly of the Nap- $\mathrm{YY}-\mathrm{NH}_{2}$ and formation of micellar Nap-Y-OH.

These structural changes were also reflected in the rheological properties of the selfassembled system. Initially, an increase of the mechanical strength from $2.79 \mathrm{KPa}$ to 2.92 $\mathrm{KPa}$ was observed (Figure S14). As soon as the hydrolysis/ dis-assembly initiates, the gel strength is reduced. After $4 \mathrm{~h}$, when the dipeptide concentration reaches around $20 \%$, the strength was found to be only $0.024 \mathrm{KPa}$, after which the gel dissolved. We then investigated whether the mechanical strength of the resulting hydrogels influences hydrolysis and dissolution. We measured the stiffness of all three gels, $\mathrm{Nap}-\mathrm{YF}-\mathrm{NH}_{2}$ giving the highest stiffnes (14.3 KPa) (Figure S15) compared to the other two (5.8 KPa for Nap-YL$\mathrm{NH}_{2}$ and $2.9 \mathrm{KPa}$ for Nap-YY-NH${ }_{2}$ ) (Figure S14 and S16). This observation could explain the corresponding dissolution rate of the peptide nanofibers with Nap-YF- $\mathrm{NH}_{2}$ taking a longer time to degrade compared to the weaker gelators.

In summary, we developed a non-equilibrium biocatalytic self-assembling system that uses chemical energy stored in a methyl ester precursor to generate a temporary high concentration of the gelator in a kinetically controlled manner. Subsequent hydrolysis of the gelator leads to the formation of nanofibers with dynamic instability. The system could be refueled several times. Such a system mimics the unique features of the natural dynamic self-assembled systems but is much simpler and accessible for future adaptive biomedical and nanotechnological applications. 


\section{AUTHOR INFORMATION}

\section{Corresponding Author}

rein.ulijn@strath.ac.uk

Notes

The authors declare no competing financial interests.

\section{ACKNOWLEDGMENT}

We thank the EPSRC, HFSP, ERC (Starting Grant EMERgE), and Leverhulme Trust (Leadership Award) (U.K.) for funding. The material is based on research sponsored by the Air Force Laboratory, under Agreement FA9550-11-1-0263.

\section{REFERENCES}

1. (a) Lehn, J. -M. Science 2002, 295, 2400-2403. (b) Whitesides, G. M.; Grzybowski, B. Science 2002, 295, 24182421. (c) Aida, T.; Meijer, E. W.; Stupp S. I. Science 2012, 335, 813-817.

2. (a) Wilner, O. I.; Weizmann, Y.; Gill, R.; Lioubashevski, O.; Freeman, R.; Willner, I. Nat. Nanotechnol. 2009, 4, 249-254. (b) Ostrov, N.; Gazit, E. Angew. Chem. Int. Ed., 2010, 49, 3018-3021. (c) Hirst, A. R.; Roy, S.; Arora, M.; Das, A. K.; Hodson, N.; Murray, P.; Marshall, S.; Javid, N.; Sefcik, J.; Boekhoven, J.; van Esch, J. H.; Santabarbara, S.; Hunt, N. T.; Ulijn, R. V. Nature Chemistry 2010, 2, 1089-1094. (d) Ku, T.-H.; Chien, M.P.; Thompson, M. P.; Sinkovits, R. S.; Olson, N. H.; Baker, T. S.; Gianneschi, N. C. J. Am. Chem. Soc. 2o11, 133, 8392-8395. (e) Li, X.; Kuang, Y.; Lin, H. -C.; Gao, Y.; Shi, j.; Xu, B. Angew. Chem. Int. Ed. 2011, 50, 93659369. (f) Hu, J.; Zhang, G.; Liu, S. Chem. Soc. Rev. 2o12, 41, 5933-5949. (g) Guo, D. -S.; Wang, K.; Wang, Y. X.; Liu Y. J. Am. Chem. Soc. 2012, 134, 10244-10250. (h) Jiang, L.; Yan, Y.; Drechsler, M.; Huang, J. Chem. Commun. 2012, 48, 7347-7349. (i) Lock, L. L.; Cheetham, A. G.; Zhang, P.; Cui, H. ACS Nano, 2013, 7, 49244932. (j) Boekhoven, J.; Poolman, J. M.; Maity, C. ; Li, F.; van der Mee, L.; Minkenberg, C. B.; Mendes, E.; van Esch, J. H.; Eelkema, R. Nature Chemistry 2013, 5, 433-437.

3. Alberts, B.; Johnson, A.; Lewis, J.; Raff, M.; Roberts, K.; Walter, P. The cytoskeleton. Molecular biology of the cell, Garland Science, New York, 2002, Chapter 16, p 907-982.

4. $\quad$ Desai. A.; Mitchison, T. J. Annu. Rev. Cell. Dev. Biol. 1997, 13, 83-117.

5. (a) Warren, S. C.; Guney-Altay, O.; Grzybowski, B. A. J. Phys. Chem. Lett. 2012, 3, 2103-2111. (b) Mann, S. Nat. Mater. 2009, 8, 781-792.

6. (a) Miras, H. N.; Sorus, M.; Hawkett, J.; Sells, D. O.; McInnes, E. J. L.; Cronin, L. J. Am. Chem. Soc. 2012, 134, 6980-6983. (b) Carnall, J. M. A.; Waudby, C. A.; Belenguer, A. M.; Stuart, M. C. A.; Peyralans, J. J.-P.; Otto, S. Science 2010, 327, 1502-1506. (c) Rubinov, B.; Wagner, N.; Matmor, M.; Regev, O.; Ashkenasy, N.; Ashkenasy, G. ACS Nano 2012, 6, 7893-7901.

7. $\quad$ Boekhoven, J.; Brizard, A. M.; Kowlgi, K. N. K.; Koper, G. J. M.; Eelkema, K.; van Esch, J. H. Angew. Chem. Int. Ed. 2010, 49, 4825-4828.

8. von Maltzahn, G.; Min, D.-H.; Zhang, Y. J..; Park, -H.; Harris, T. J.; Sailor, M.; Bhatia, S. N. Adv. Mater. 2007, 19, 3579-3583.

9. (a) Winkler, S.; Wilson, D.; Kaplan, D. L. Biochemistry 2ooo, 39, 12739-12746. (b) Yang, Z.; Liang, G.; Wang, L.; Xu, B. J. Am. Chem. Soc. 2006, 128, 3038-3043. (c) Webber, M. J.; Newcomb, C. J.; Bitton, R.; Stupp, S. I. Soft Matter 2011, 7, 9665-9672.

10. (a) Yang, Z.; Liang, G.; Ma, M.; Gao, Y.; Xu, B. J. Mater. Chem. 2oo7, 17, 850-854. (b) Chen, L.; Morris, K.; Laybourn, A.; Elias, D.; Hicks, M. R.; Rodger, A.; Serpell, L.; Adams, D. J. Langmuir 2010, 26, 5232-5242. (c) Nalluri, S. K. M.; Ulijn, R. V. Chem. Sci. 2013, 4, 3699-3705.

11. (a) Fastrez, J.; Fersht, A. R. Biochemistry 1973, 12, 2025-2034. (b) Morihara, K.; Oka, T. Biochem. J. 1977, 163, 531-542. (c) Bordusa, F. Chem. Rev. 2002, 102, 4817-4867.

12. (a) Toledano, S.; Williams, R. J.; Jayawarna, V.; Ulijn, R. V. J. Am. Chem. Soc. 2006, 128, 1070-1071. (b) Williams, R. J.; Smith, A. M.; Collins, R.; Hodson, N.; Das, A. K.; Ulijn, R. V. Nat. Nanotechnol., 20o9, 4, 1924

13. Qin, X.; Xie, W.; Tian, S.; Cai, J.; Yuan, H.; Yu, Z.; Butterfoss, G. L.; Khuonga, A. C.; Gross, R. A. Chem. Commun. 2013, 49, 4839-4841.

14. In our previous paper, yields obtained through thermolysin catalysed condensation were slightly higher due to the use of a 1:4 molar ratio of Nap-Y and L/Y-NH

15. (a) Gao, J.; Wang, H.; Wang, L.; Wang, J.; Kong, D.; Yang, Z. J. Am. Chem. Soc. 2009, 131, 11286-11287. (b) Channon, K. J.; Devlin, G. L.; Magennis, S. W.; Finlayson, C. E.; Tickler, A. K.; Silva, C.; MacPhee C. E. J. Am. Chem. Soc. 2008, 130, 5487-5491.

16. (a) Saha, A.; Manna, S.; Nandi, A. K. Langmuir 2007, 23, 13126-13135. (b) Kimura, M.; Kitamura, T.; Sano, M.; Muto, T.; Hanabusa, K.; Shiraia, H.; Kobayashi, N. New J. Chem. 2ooo, 24, 113-114. 


\section{Supporting Information}

Materials.L-Tyrosine methyl ester hydrochloride, 2-Naphthoxyacetic acid, N,NDiisopropylethylamine (DIPEA) $(>99.5 \%)$ were purchased from Sigma-Aldrich and used as received. 2-(1H-Benzotriazole-1-yl)-1,1,3,3-tetramethyluronium hexafluorophosphate (HBTU) was purchased from Novabiochem. The reactions were followed by Thin Layer Chromatography (TLC) plates, revealed by a UV-lamp at $254 \mathrm{~nm}$. All other reagents and materials from commercial sources were used without further purification. Silica gel used in chromatographic separations was obtained VWR (Silica Gel, ultra pure, 40-60 mm). NMR spectra were recorded in AVANCE $400 \mathrm{MHz}$ (BRUKER) spectrometer.

\section{Synthesis:}

Synthesis of Nap-Y-Ome (1): $1 \mathrm{gm}$ of 2-Naphthoxyacetic acid (4.94 mmol), $1.14 \mathrm{gm}$ of L-Tyrosine methyl ester hydrochloride $(4.94 \mathrm{mmol})$ and $2.06 \mathrm{gm}$ of HBTU $(5.43 \mathrm{mmol})$ were dissolved in $10 \mathrm{~mL}$ of dry DMF. Then $2.27 \mathrm{~mL}(12.36 \mathrm{mmol})$ of DIPEA was added to this solution and the reaction mixture was stirred for overnight under nitrogen atmosphere. After reaction, the product was extracted by $50 \mathrm{~mL}$ of ethyl acetate after successive wash with $20 \mathrm{~mL}$ of $1 \mathrm{~N} \mathrm{NaHCO}$ and $20 \mathrm{~mL}$ of $1 \mathrm{~N}$ hydrochloric acid and then dried over $\mathrm{MgSO}_{4}$. After evaporation of the solvent, the compound NapY-Ome (1) was purified by column chromatography on silica gel using dichloromethane/ methanol $(96: 4)$ as eluent. The yield of the product is $1.51 \mathrm{gm}(80 \%)$.<smiles>COC(=O)C(N)Cc1ccc2ccc(OCC(=O)NC(Cc3ccc(O)cc3)C(=O)OC)cc2c1</smiles>

${ }^{1} \mathrm{H}$ NMR (DMSO- $\left.\mathrm{d}_{6}, 400 \mathrm{MHz}\right) \delta$ 2.88-3.09 (m, 2H, $\mathrm{CH}_{2}$ in tyrosine moiety), 3.61 (s, 3H, $\mathrm{OCH}_{3}$ ), 4.5-4.55 ( $\mathrm{m}, 1 \mathrm{H}, \mathrm{CH}$ in tyrosine moiety), $4.61\left(\mathrm{~s}, 2 \mathrm{H}, \mathrm{OCH}_{2} \mathrm{CO}\right), 6.64(\mathrm{~d}, 2 \mathrm{H}, \mathrm{CH}$ at ortho position of $\mathrm{OH}$ group of tyrosine, $\left.{ }^{3} \mathrm{~J}=8.8 \mathrm{~Hz}\right), 7.00\left(\mathrm{~d}, 2 \mathrm{H}, \mathrm{CH}\right.$ at meta position of $\mathrm{OH}$ group of tyrosine, $\left.{ }^{3} \mathrm{~J}=8.8 \mathrm{~Hz}\right), 7.20$ $7.29(\mathrm{~m}, 2 \mathrm{H}$, naphthalene aromatic $\mathrm{CH}), 7.34-7.38(\mathrm{~m}, 1 \mathrm{H}$, naphthalene aromatic $\mathrm{CH}), 7.45-7.49(\mathrm{~m}$, $1 \mathrm{H}$, naphthalene aromatic $\mathrm{CH}), 7.75\left(\mathrm{~d}, 1 \mathrm{H}\right.$, naphthalene aromatic $\left.\mathrm{CH},{ }^{3} \mathrm{~J}=7.6 \mathrm{~Hz}\right), 7.83-7.86(\mathrm{~m}, 2 \mathrm{H}$, naphthalene aromatic $\mathrm{CH}$ ), $8.43\left(\mathrm{~d}, 1 \mathrm{H}, \mathrm{CONH},{ }^{3} \mathrm{~J}=7.6 \mathrm{~Hz}\right), 9.22(\mathrm{~s}, 1 \mathrm{H}, \mathrm{OH}) .{ }^{13} \mathrm{C}$ NMR (DMSO, 100 $\mathrm{MHz}): \delta 35.7\left(\mathrm{Tyr} \mathrm{CH}_{2}\right), 51.9\left(\mathrm{OCH}_{3}\right), 53.5$ (Tyr chiral $\left.\mathrm{CH}\right), 66.6\left(\mathrm{OCH}_{2}\right), 107.4(\mathrm{Ar} \mathrm{CH}), 115.1(\mathrm{Ar} \mathrm{CH})$, 118.5 ( $\mathrm{ArCH}), 123.8(\mathrm{Ar} \mathrm{CH}), 126.4\left(\operatorname{ArC}_{\mathrm{q}}\right), 126.7(\mathrm{Ar} \mathrm{CH}), 127.0\left(\operatorname{ArC}_{\mathrm{q}}\right), 127.5(\mathrm{Ar} \mathrm{CH}), 128.7(\mathrm{Ar} \mathrm{CH})$, 129.3 ( $\mathrm{ArCH}), 130.0(\mathrm{ArCH}), 134.0\left(\mathrm{ArC}_{\mathrm{q}}\right), 155.5\left(\mathrm{ArC}_{\mathrm{q}}\right), 156.0\left(\mathrm{ArC}_{\mathrm{q}}\right), 167.6(\mathrm{C}=\mathrm{O}), 171.8(\mathrm{C}=\mathrm{O})$.

Synthesis of Nap-Y-OH (3): 0.5 gm of Nap-Y-OMe was dissolved in $5 \mathrm{~mL}$ of methanol followed by addition of $2.5 \mathrm{~mL}$ of $2(\mathrm{~N}) \mathrm{NaOH}$ solution in the mixture. This solution was stirred for 4 hours. After 
the reaction is over, methanol was evaporated under low pressure. Then the aqueous solution of the sodium salt of the compound was washed with diethyl ether. Then the compound was precipitated out from the solution after addition of $20 \mathrm{~mL} 1(\mathrm{~N}) \mathrm{HCl}$. Finally the compound was extracted with 20 $\mathrm{mL}$ of ethyl acetate and then dried over $\mathrm{MgSO}_{4}$. After evaporation of the solvent, the pure compound Nap-Y-OH (3) was obtainedin very high yield (0.45gm, 93\%).<smiles>COC(=O)C(Cc1ccc(O)cc1)NC(=O)COc1ccc2ccccc2c1</smiles>

${ }^{1} \mathrm{H}$ NMR (DMSO- $\left.\mathrm{d}_{6}, 400 \mathrm{MHz}\right) \delta 2.86-3.03\left(\mathrm{~m}, 2 \mathrm{H}, \mathrm{CH}_{2}\right.$ in tyrosine moiety), 4.43-4.48 (m, $1 \mathrm{H}, \mathrm{CH}$ in tyrosine moiety), $4.6\left(\mathrm{~s}, 2 \mathrm{H}, \mathrm{OCH}_{2} \mathrm{CO}\right), 6.62\left(\mathrm{~d}, 2 \mathrm{H}, \mathrm{CH}\right.$ at ortho position of $\mathrm{OH}$ group of tyrosine, ${ }^{3} \mathrm{~J}=$ $8.4 \mathrm{~Hz}), 7.00\left(\mathrm{~d}, 2 \mathrm{H}, \mathrm{CH}\right.$ at meta position of $\mathrm{OH}$ group of tyrosine, $\left.{ }^{3} \mathrm{~J}=8.8 \mathrm{~Hz}\right), 7.19-7.24(\mathrm{~m}$, $2 \mathrm{H}$, naphthalene aromatic $\mathrm{CH}), 7.34-7.38(\mathrm{~m}, 1 \mathrm{H}$, naphthalene aromatic $\mathrm{CH}), 7.44-7.48(\mathrm{~m}, 1 \mathrm{H}$, naphthalene aromatic $\mathrm{CH}), 7.74\left(\mathrm{~d}, 1 \mathrm{H}\right.$, naphthalene aromatic $\left.\mathrm{CH},{ }^{3} \mathrm{~J}=7.6 \mathrm{~Hz}\right), 7.83-7.85(\mathrm{~m}, 2 \mathrm{H}$, naphthalene aromatic $\mathrm{CH}), 8.21\left(\mathrm{~d}, 1 \mathrm{H}, \mathrm{CONH},{ }^{3} \mathrm{~J}=8.4 \mathrm{~Hz}\right), 9.22(\mathrm{~s}, 1 \mathrm{H}, \mathrm{OH}), 12.90(\mathrm{~s}, 1 \mathrm{H}, \mathrm{COOH}) .{ }^{13} \mathrm{C}$ NMR (DMSO, $100 \mathrm{MHz}$ ): $\delta 35.7$ (Tyr CH $\mathrm{CH}_{2}$ ), 53.4 (Tyr chiral CH), $66.7\left(\mathrm{OCH}_{2}\right), 107.4(\mathrm{Ar} \mathrm{CH}), 115.0(\mathrm{Ar}$ $\mathrm{CH}), 118.4(\mathrm{ArCH}), 123.8(\mathrm{Ar} \mathrm{CH}), 126.4\left(\mathrm{ArC}_{\mathrm{q}}\right), 126.7(\mathrm{Ar} \mathrm{CH}), 127.4\left(\mathrm{ArC}_{\mathrm{q}}\right), 127.5(\mathrm{Ar} \mathrm{CH}), 128.7(\mathrm{Ar}$ $\mathrm{CH}), 129.3(\mathrm{ArCH}), 130.0(\mathrm{ArCH}), 134.0\left(\operatorname{ArC}_{\mathrm{q}}\right), 155.5\left(\operatorname{ArC}_{\mathrm{q}}\right), 155.9\left(\mathrm{ArC}_{\mathrm{q}}\right), 167.4(\mathrm{C}=\mathrm{O}), 172.8(\mathrm{C}=\mathrm{O})$.

Bio-catalytic hydrogelation. $7.6 \mathrm{mg}$ of Nap-Y-OMe $(20 \mathrm{mM}), 20 \mathrm{mM}$ of required amino acid amide and $1 \mathrm{mg}$ of $\alpha$-chymotrypsin were dissolved in $100 \mu \mathrm{L}$ of DMSO. Then $900 \mu \mathrm{L}$ of required buffer (for $\mathrm{pH} 8$ and 9, $100 \mathrm{mM}$ phosphate buffer and for $\mathrm{pH} 10,100 \mathrm{mM}$ of $\mathrm{NaHCO}_{3} / \mathrm{NaOH}$ buffer were used) was added in the solution and stirred very well. Within 2 minutes the gels were formed. Gelation was considered to have occurred when a homogeneous "solid-like" material was obtained that exhibited no gravitational flow. All the time depended experiments were done with this gel. For refuelling experiments $50 \mu \mathrm{L}$ of DMSO was used instead of $100 \mu \mathrm{L}$.

Fluorescence Spectroscopy. Fluorescence emission spectra were measured on a Jasco FP-6500 spectrofluorometer with light measured orthogonally to the excitation light, at a scanning speed of $100 \mathrm{~nm} \mathrm{~min}{ }^{-1}$. The gel was prepared by the reaction of $20 \mathrm{mM} \mathrm{Nap}-\mathrm{Y}-\mathrm{OMe}$ with $20 \mathrm{mM}$ of Y-NH $\mathrm{NH}_{2}$ presence of $1 \mathrm{mg}$ of chymotrypsin as mentioned earlier.The excitation wavelength was $280 \mathrm{~nm}$, and emission data were recorded in the range between 300 and $500 \mathrm{~nm}$. The spectra were measured with a bandwidth of $3 \mathrm{~nm}$ with a medium response and a $1 \mathrm{~nm}$ data pitch. Quartz cells with a path length of $10 \mathrm{~mm}$ were used for the study.

Circular Dichroism(CD). CD Spectra were measured on a Jasco J600 spectropolarimeter with $1 \mathrm{~s}$ integrations with a step size of $1 \mathrm{~nm}$ and a single acquisition with a slit width of $1 \mathrm{~nm}$. The gel was prepared by the reaction of $20 \mathrm{mM}$ Nap-Y-OMe with $20 \mathrm{mM}$ of $\mathrm{Y}-\mathrm{NH}_{2}$ in presence of $1 \mathrm{mg}$ of chymotrypsin as mentioned earlier.Quartz cells of $0.2 \mathrm{~mm}$ path length were used for the measurement. 
Atomic Force Microscopy (AFM): Atomic force microscopy (AFM) measurements were performed using a VeecoMultiMode with NanoScope IIID Controller Scanning Probe Microscope. After the preparation of the gel of Nap-YY- $\mathrm{NH}_{2}$ by aforementioned protocol, a part of the gel was diluted to 5 times with double distilled water at different time point and cast $10 \mu \mathrm{L}$ of diluted sample on the mica plate and dried immediately by gentle blow of airbefore imaging.

High-Performance Liquid Chromatography (HPLC). A Dionex P680 HPLC pump was used to quantify conversions of the enzymatic reaction. A $20 \mu \mathrm{L}$ sample was injected onto a Macherey-Nagel C18 column of $250 \mathrm{~mm}$ length with an internal diameter of $4.6 \mathrm{~mm}$ and $5 \mathrm{~mm}$ fused silica particles at a flow rate of $1 \mathrm{~mL} \mathrm{~min}^{-1}$ [eluting solvent system: linear gradient of $20 \%(\mathrm{v} / \mathrm{v})$ acetonitrile in water for 4 min and gradually rising to $80 \%(\mathrm{v} / \mathrm{v})$ acetonitrile in water at $35 \mathrm{~min}$; this concentration was kept constant until $40 \mathrm{~min}$ when the gradient was decreased to $20 \%(\mathrm{v} / \mathrm{v})$ acetonitrile in water at $42 \mathrm{~min}$ ]. The sample preparation involved mixing $50 \mu \mathrm{L}$ of gel with acetonitrile-water (950 $\mu \mathrm{L}, 50: 50$ mixture) containing $0.1 \%$ trifluoroacetic acid. The purity of each identified peak was determined by the ultraviolet (UV) detection at $280 \mathrm{~nm}$. The HPLC samples were prepared at different time intervals after preparing the gel as mentioned earlier.

Oscillatory Rheology. To verify the mechanical properties of the resulting hydrogels, dynamic frequency sweep experiments were carried out on a strain-controlled rheometer (Kinexus Pro rheometer) using parallel-plate geometry ( $20 \mathrm{~mm}$ diameter). The experiments were performed at 25 ${ }^{\circ} \mathrm{C}$, and this temperature was controlled throughout the experiment using an integrated electrical heater. Additional precautions were taken to minimize solvent evaporation and to keep the sample hydrated: a solvent trap was used, and the internal atmosphere was kept saturated. To ensure that the measurements were made in the linear viscoelastic regime, an amplitude sweep was performed and the results showed no variation in elastic modulus $\left(G^{\prime}\right)$ and viscous modulus $\left(G^{\prime \prime}\right)$ up to a strain of $1 \%$. The dynamic modulus of the hydrogel was measured as a frequency function, where the frequency sweeps were carried out between 0.1 and $100 \mathrm{~Hz}$. The gels were made in small fractions in wide-mouth vials from which they were transferred with a spatula for rheological measurements. The measurements were repeated 3 times to ensure reproducibility, with the average data shown. 


\section{Results:}
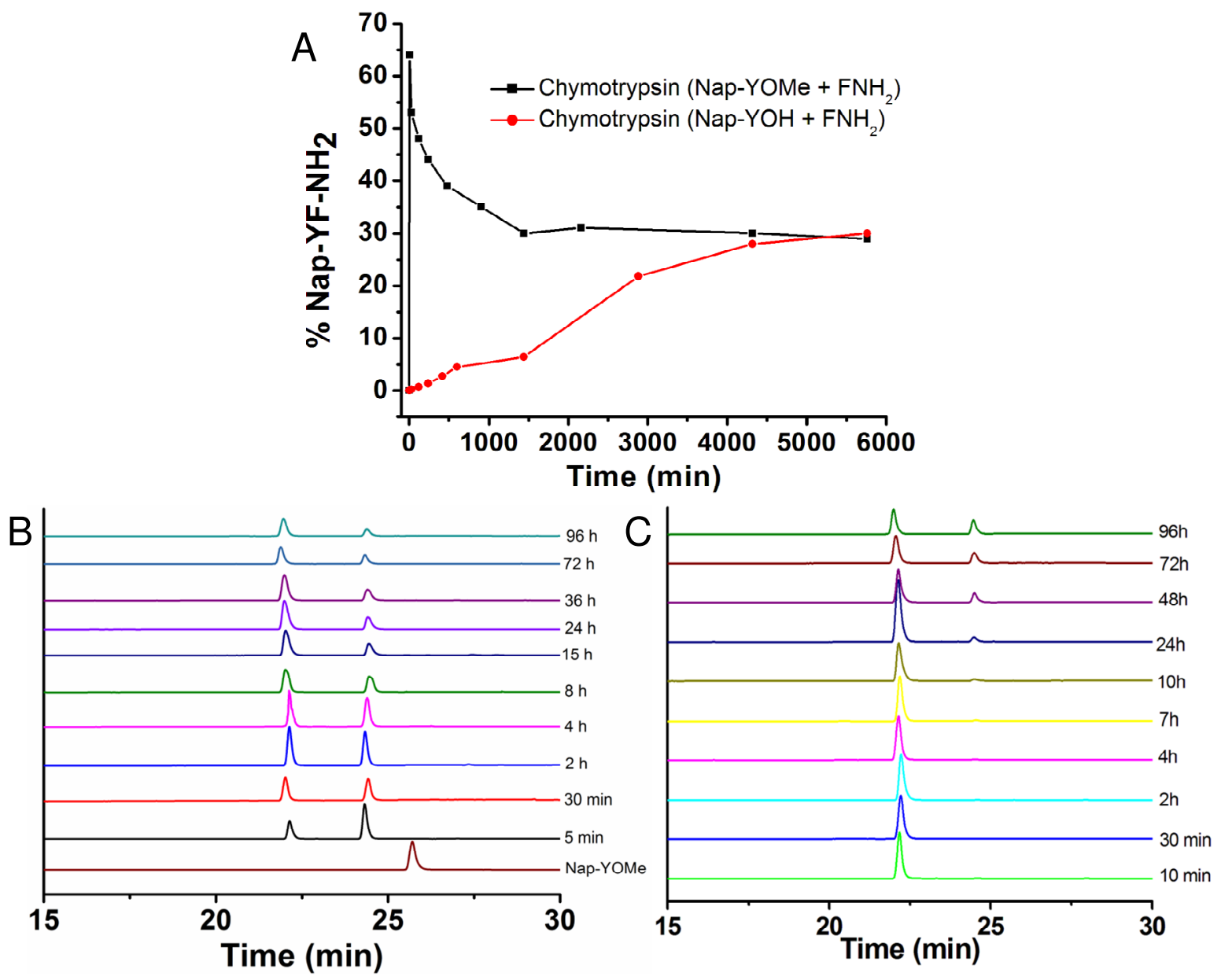

Figure S1. (A) Reaction profile of Nap-Y-OMe and Nap-Y-OH with $\mathrm{F}-\mathrm{NH}_{2}$ in presence of $1 \mathrm{mg}$ of chymotrypsin at $\mathrm{pH}$ 8. (B-C) The corresponding chromatograms of the reaction of Nap-Y-OMe and Nap-Y-OH with F-NH $\mathrm{N}_{2}$ repectively.
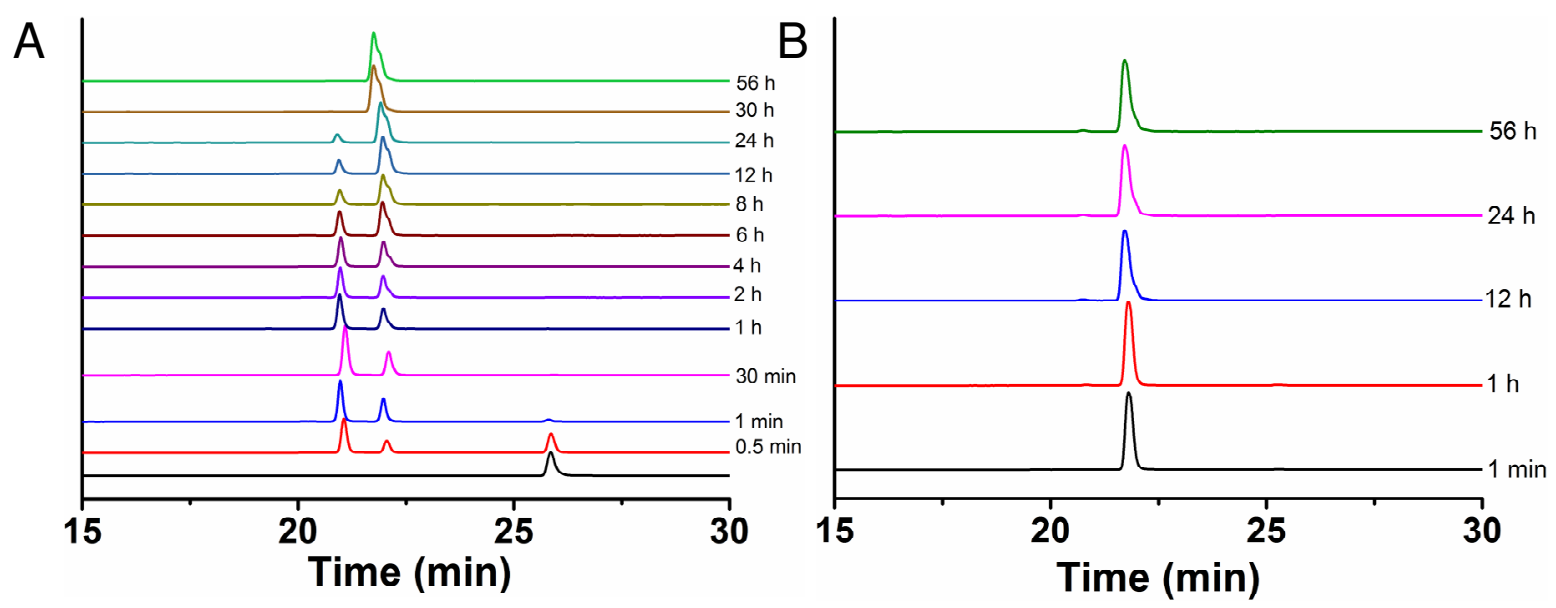

Figure S2. (A-B)HPLC chromatograms (corresponding to Figure 1B) of the reaction between Nap-YOMe and Nap-Y-OH with $\mathrm{Y}-\mathrm{NH}_{2}$ in presence of $1 \mathrm{mg}$ of chymotrysin (kinetic control reaction) and 1 $\mathrm{mg}$ of thermolysin(thermodynamic control reaction) respectively at $\mathrm{pH} 8$. 


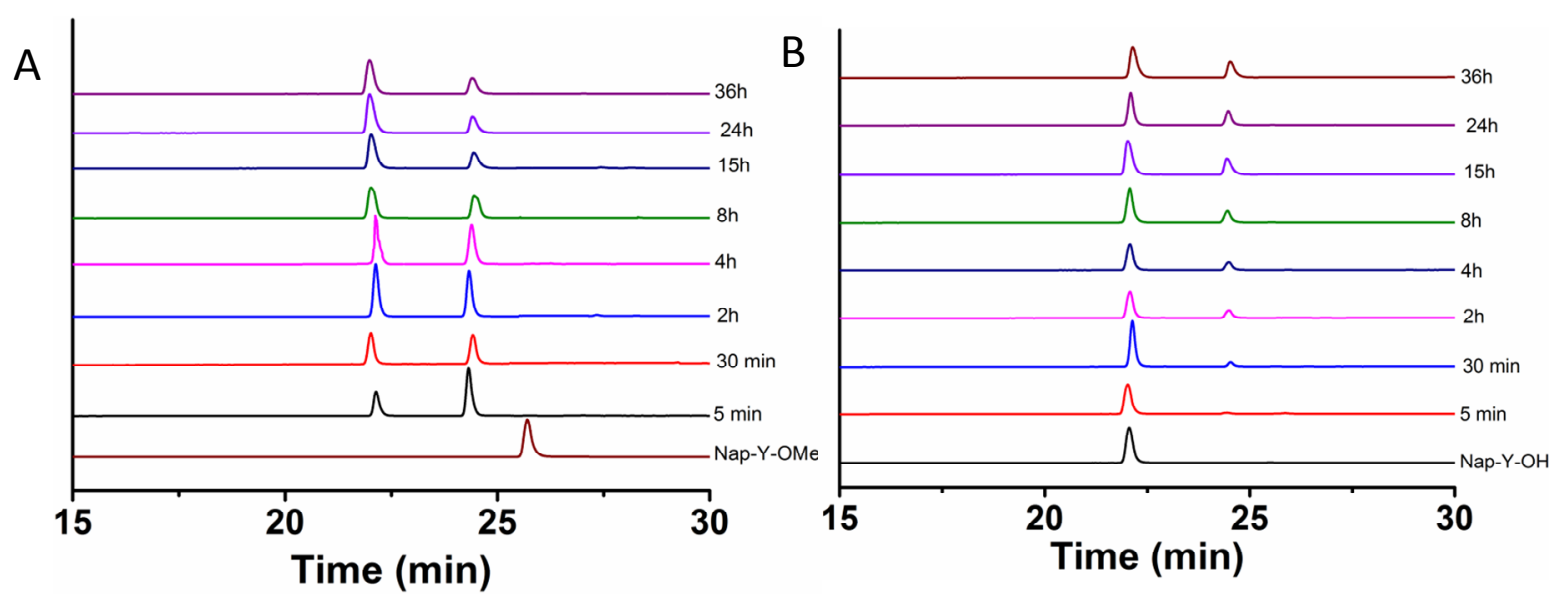

Figure S3. (A-B)HPLC chromatograms (corresponding to Figure 1C) of the reaction between Nap-Y$\mathrm{OMe}$ and $\mathrm{Nap}-\mathrm{Y}-\mathrm{OH}$ with $\mathrm{F}-\mathrm{NH}_{2}$ in presence of $1 \mathrm{mg}$ of chymotrysin (kinetic control reaction) and 1 $\mathrm{mg}$ of thermolysin (thermodynamic control reaction)respectively at $\mathrm{pH} 8$.
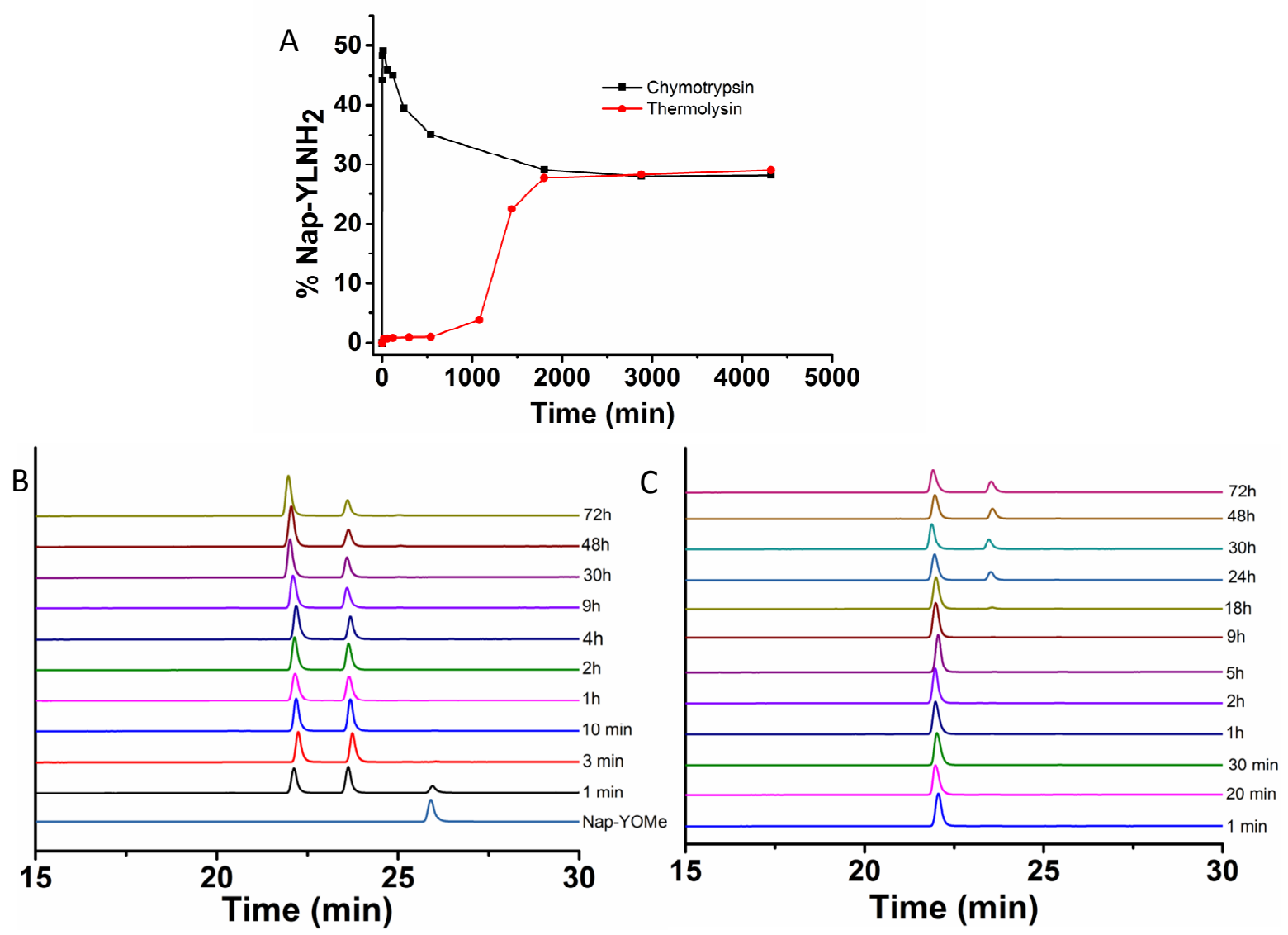

Figure S4. (A) Reaction profile of Nap-Y-OMe and Nap-Y-OH with L-NH $\mathrm{NH}_{2}$ in presence of $1 \mathrm{mg}$ of chymotrypsin (kinetic control reaction) and $1 \mathrm{mg}$ of thermolysin (thermodynamic control reaction) respectively at $\mathrm{pH}$ 8. (B-C) The corresponding chromatograms of the reactions of Nap-Y-OMe and Nap-Y-OH with L-NH ${ }_{2}$ repectively. 


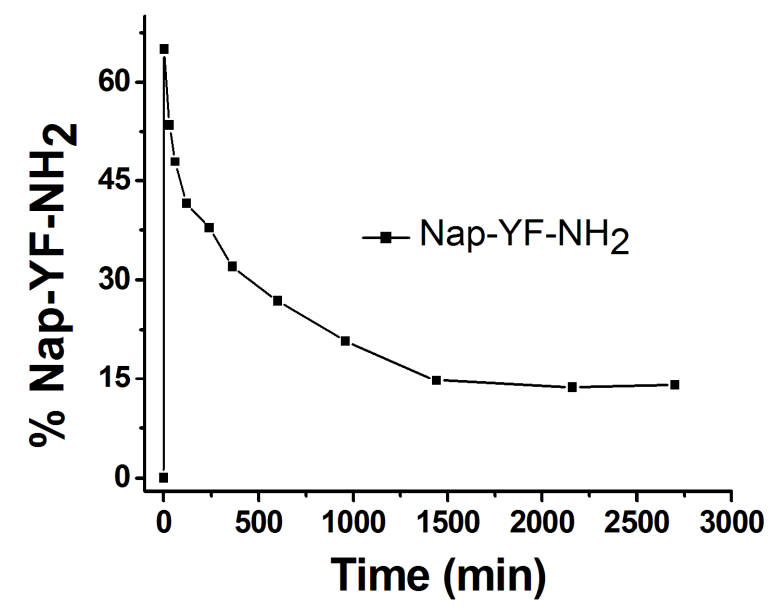

Figure S5. Synthesis and degradation of Nap-YF- $\mathrm{NH}_{2}$ in the course of time in the presence of $1 \mathrm{mg}$ of chymotrypsinat $\mathrm{pH} 10$.

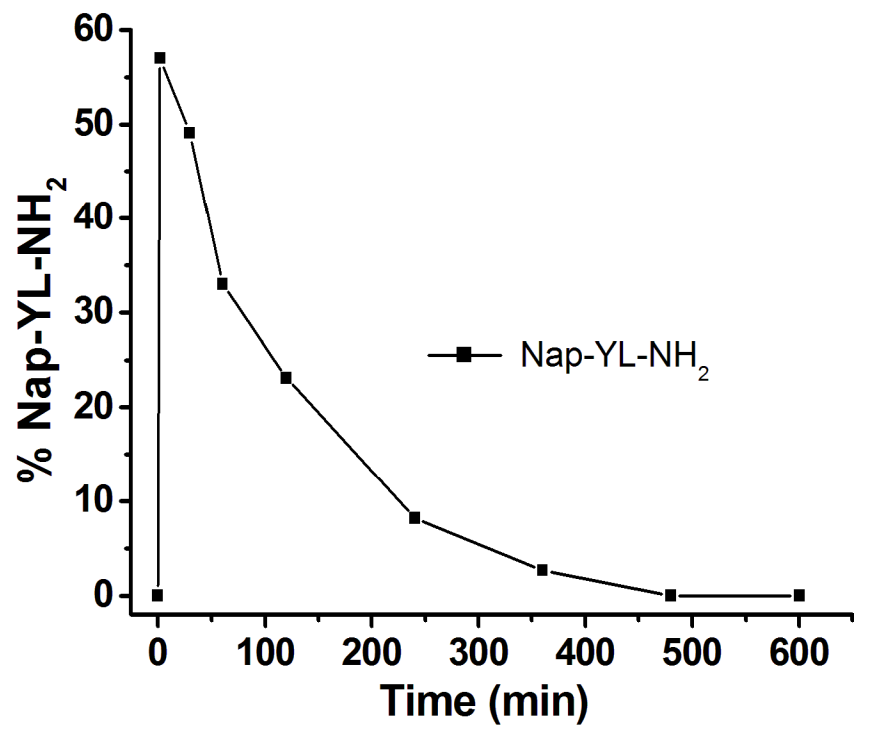

Figure S6. Synthesis and degradation of Nap-YL- $\mathrm{NH}_{2}$ in the course of time in the presence of $1 \mathrm{mg}$ of chymotrypsin at $\mathrm{pH} 10$. 


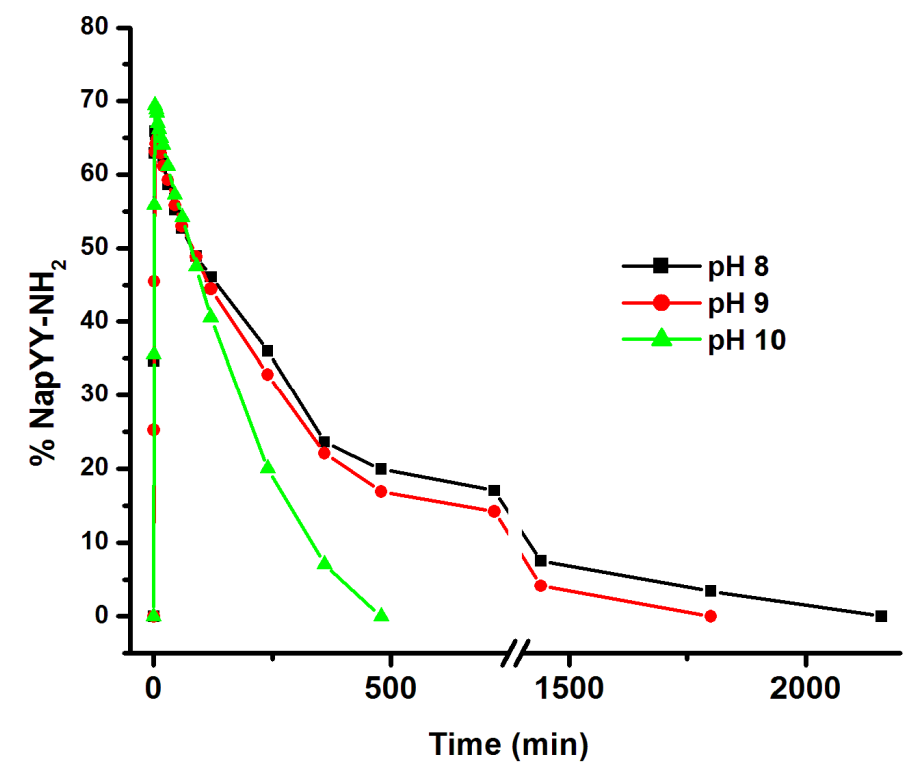

Figure S7. $\mathrm{pH}$ dependent change of reaction kinetics of the reaction between $\mathrm{Nap}-\mathrm{Y}-\mathrm{OMe}$ and $\mathrm{Y}-\mathrm{NH}_{2}$ in presence of $1 \mathrm{mg}$ of chymotrypsin.

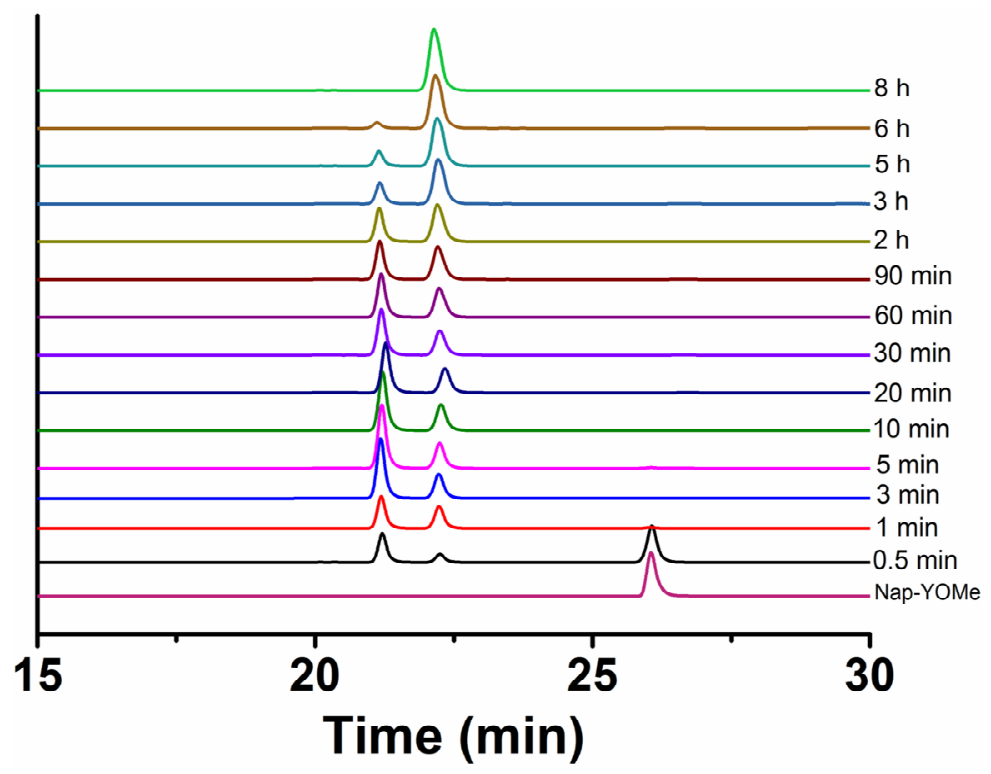

Figure S8. Representative HPLC chromatograms of the reaction between Nap-Y-OMe and $\mathrm{Y}-\mathrm{NH}_{2}$ in presence of $1 \mathrm{mg}$ of chymotrysin at $\mathrm{pH} 10$. 


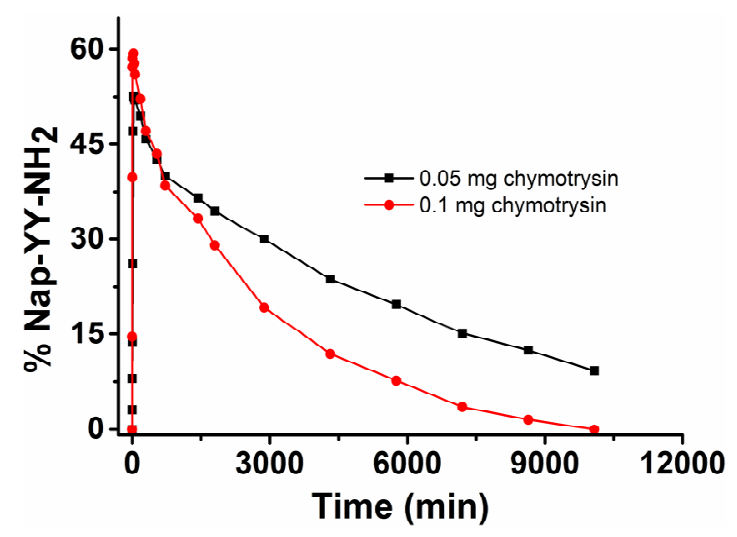

Figure S9. Synthesis and degradation of Nap-YY- $\mathrm{NH}_{2}$ with time in the presence of 0.1 and $0.05 \mathrm{mg}$ of chymotrypsin respectively.

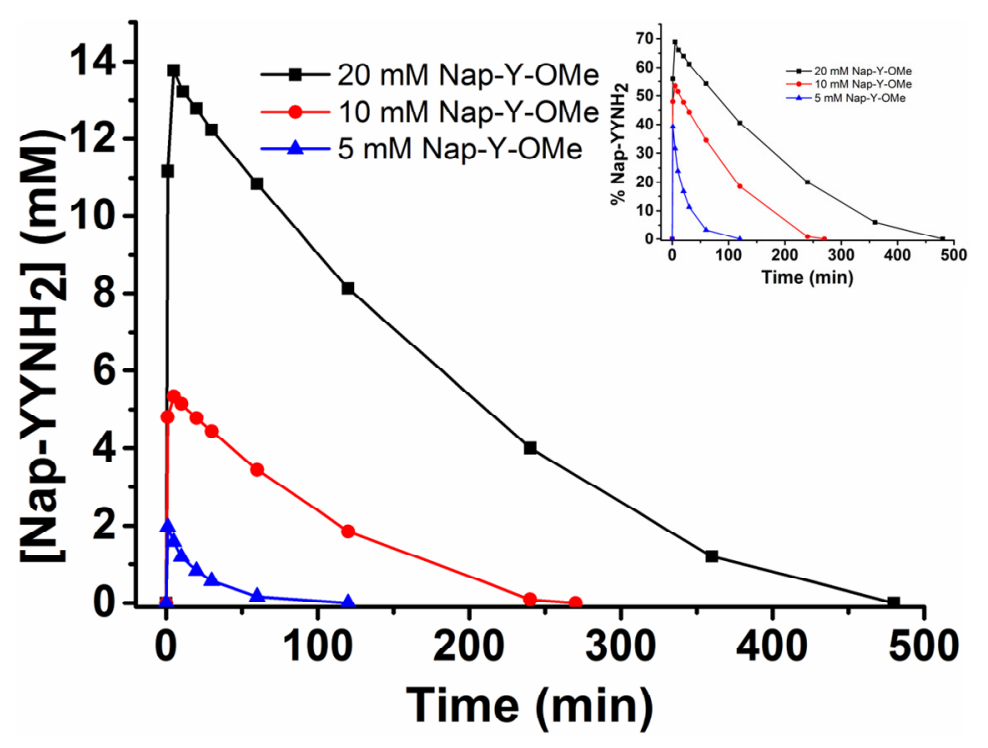

Figure S10. The synthesis and dissolution of $\mathrm{Nap}-\mathrm{YY}-\mathrm{NH}_{2}$ in presence of chymotrypsin (1mg) at $\mathrm{pH} 10$ at different concentration of NAP-Y-OMe. Inset shows the \% conversion of the respective systems. 


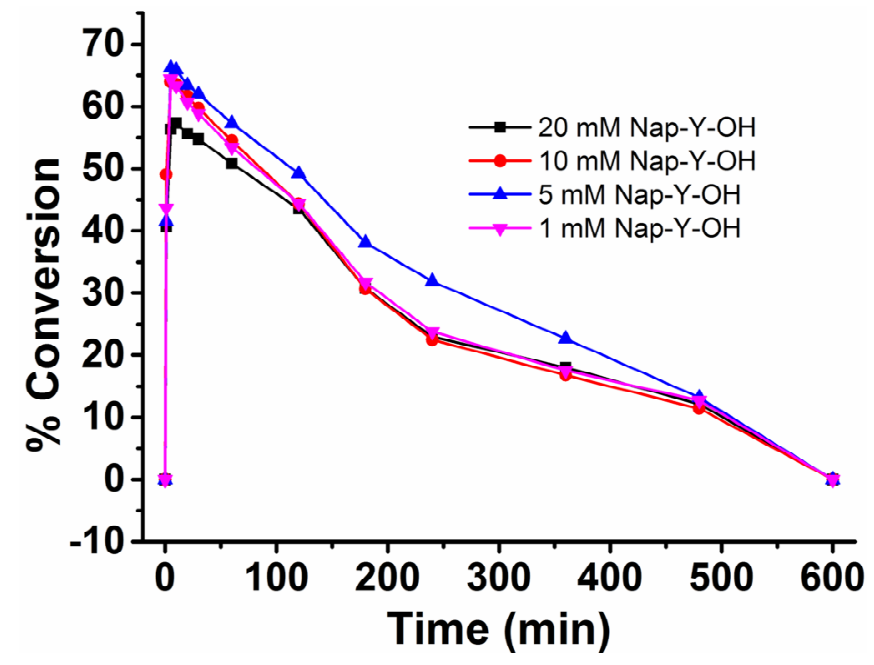

Figure S11. The synthesis and dissolution of Nap- $-\mathrm{YY}_{-}-\mathrm{NH}_{2}$ by chymotrypsin $(1 \mathrm{mg})$ at $\mathrm{pH} 10$ in presence of different concentration of NAP-Y-OH (Concentration of Nap-Y-Ome is $20 \mathrm{mM}$ ).
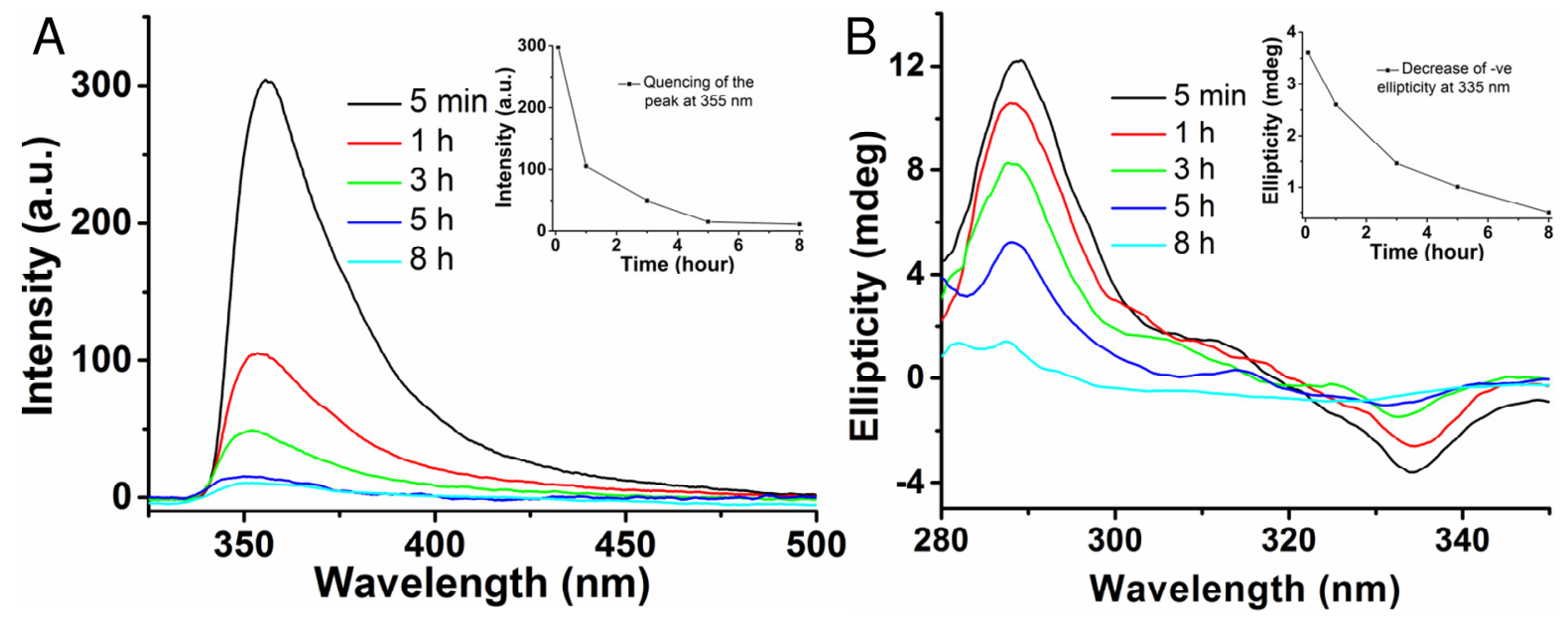

Figure S12. (A) Time dependent fluorescence spectra of the reaction between Nap-Y-OMe and Y$\mathrm{NH}_{2}, \lambda_{\text {excitation }}=280 \mathrm{~nm}$. The inset in (A) illustrates the quenching of the fluorescence intensity at 355 $\mathrm{nm}$ with time. (B) Time dependent circular dichroism (CD) spectroscopy of the reaction between $\mathrm{Nap}-\mathrm{Y}-\mathrm{OMe}$ and $\mathrm{Y}-\mathrm{NH}_{2}$ in presence of $\alpha$-chymotrypsin. The inset in (B) illustrates the decrease of the $\mathrm{CD}$ signal with time at $335 \mathrm{~nm}$. Spectra before 5 minutes are excluded due to extensive scattering of the turbid reaction mixture. 


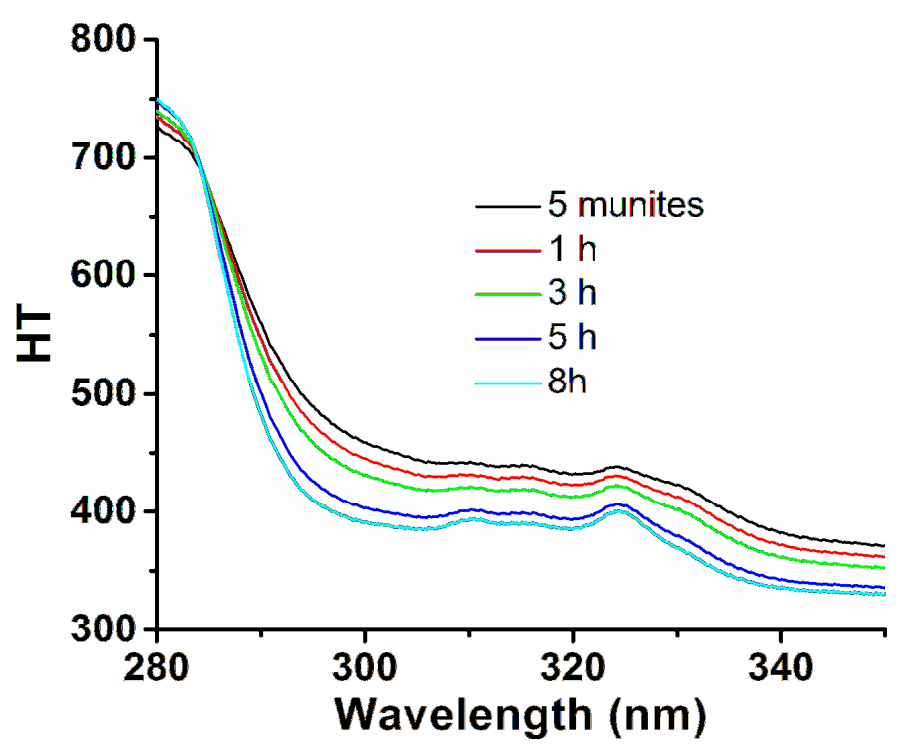

Figure S13.Corresponding HT data of CD spectra of Figure S12B. 

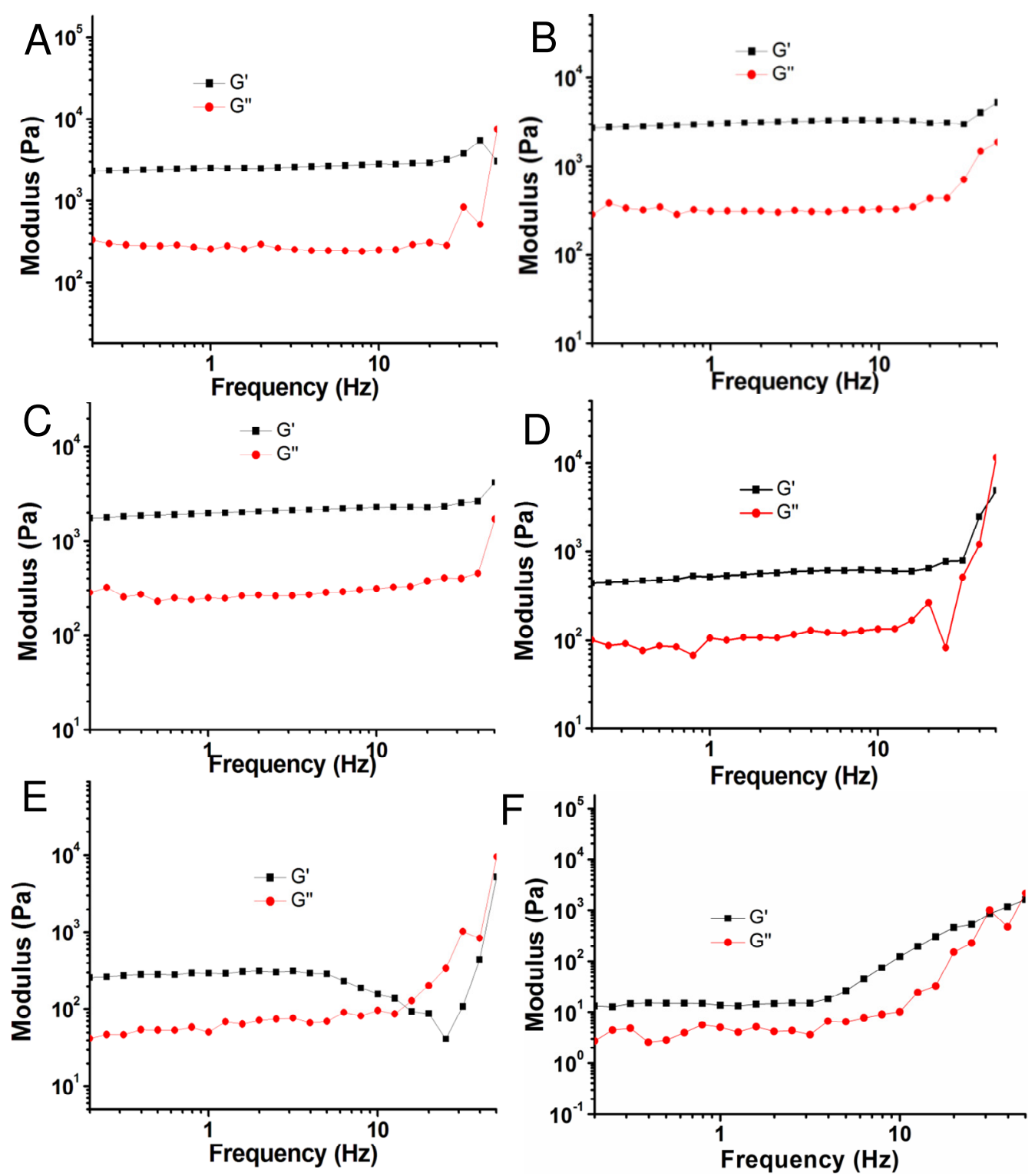

Figure S14. (A-F) Rheological data for the synthesis and degradation of Nap-YY- $\mathrm{NH}_{2}$ in the presence of $1 \mathrm{mg}$ of chymotrypsin at $10 \mathrm{~min}, 30 \mathrm{~min}, 1 \mathrm{~h}, 2 \mathrm{~h}, 3 \mathrm{~h}$, and $4 \mathrm{~h}$ respectively at $\mathrm{pH} 10$. 

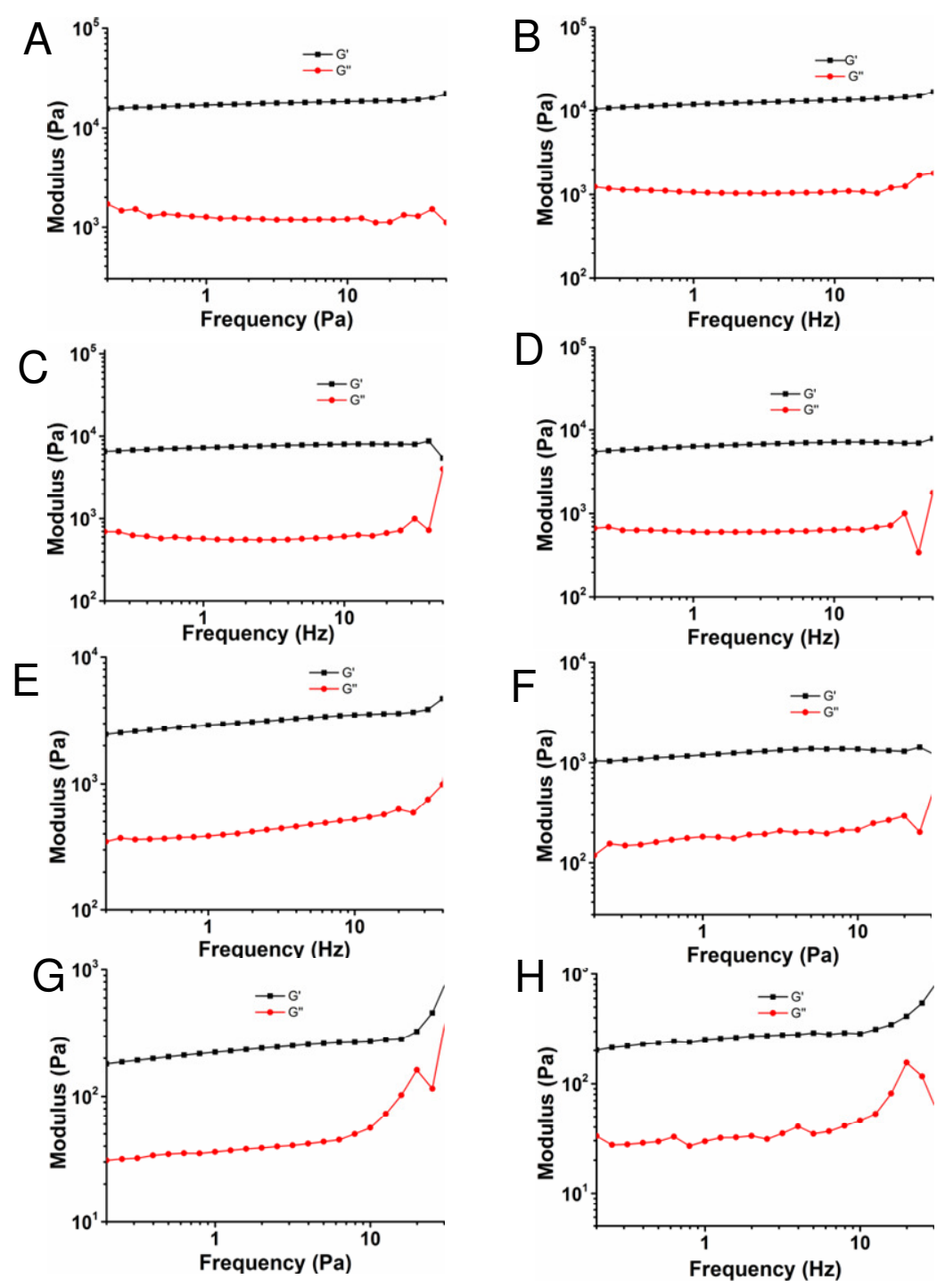

Figure S15. (A-H) Rheological data for the synthesis and degradation of Nap-YF- $\mathrm{NH}_{2}$ in the presence of $1 \mathrm{mg}$ of chymotrypsin at $\mathrm{pH} 10$ at $10 \mathrm{~min}, 30 \mathrm{~min}, 1 \mathrm{~h}, 2 \mathrm{~h}, 5 \mathrm{~h}, 18 \mathrm{~h}, 24 \mathrm{~h}$ and $40 \mathrm{~h}$ respectively. 

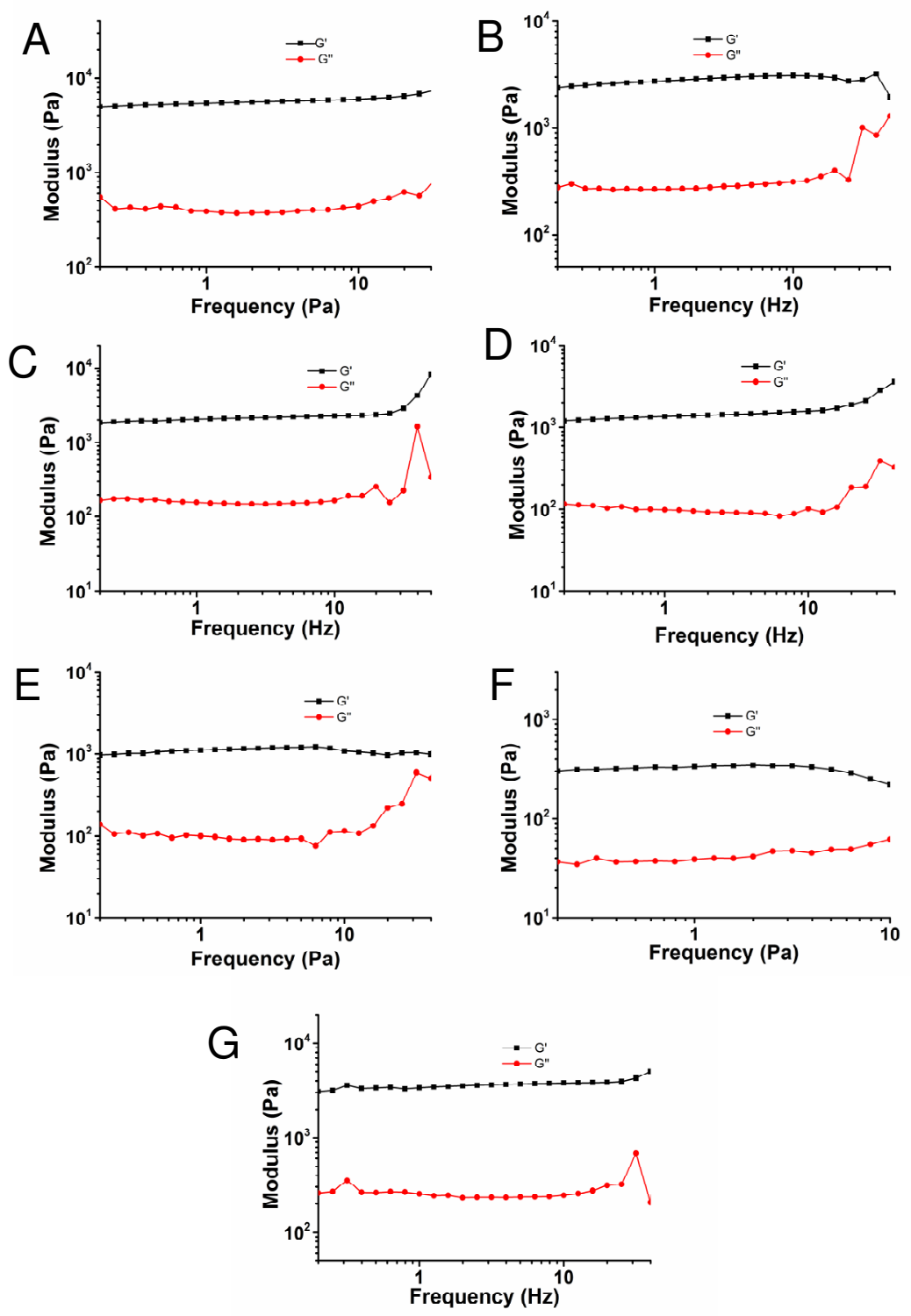

Figure S16. (A-G)Rheological data for the synthesis and degradation of Nap-YL-NH $\mathrm{NH}_{2}$ in the presence of $1 \mathrm{mg}$ of chymotrypsin at $\mathrm{pH} 10$ at $10 \mathrm{~min}, 30 \mathrm{~min}, 1 \mathrm{~h}, 2 \mathrm{~h}, 3 \mathrm{~h}, 4 \mathrm{~h}$ and $5 \mathrm{~h}$ respectively. 